\title{
Control of Yucca By Aerial Application of Herbicides ${ }^{1}$
}

\author{
R. W. BOVEY \\ Crops Research Division, ARS, USDA, Department of \\ Range and Forestry, Texas $A \& M$ University, College \\ Station, Texas ${ }^{2}$
}

Yucca (Yucca glauca Nutt.), also commonly called soapweed, beargrass, or Spanish bayonet, is a generally undesirable perennial that occurs on thousands of acres of rangeland in Nebraska and surrounding states. The plant grows to a height of 1 to 3 feet and possesses many long, thick, sharp-pointed leaves with thready margins (Figure 1). Robison (1961) described yucca as a xerophytic plant with a large deep root system that serves as a storage organ for food reserves and moisture which enables the plant to survive drought. The sharp-pointed leaves form a rosette that resists excessive transpiration loss under adverse conditions.

Aerial application studies conducted by Robison (1961) in Texas revealed that 2,4,5-trichlorophenoxy acetic acid $(2,4,5-\mathrm{T})$ and 2-(2,4,5-trichlorophenoxy propionic acid (silvex) gave the most consistent results of several herbicides applied. Treated areas produced an average of 1,831 pounds (oven-dry) of forage per acre compared to 846 pounds on untreated plots.

Preliminary yucca control studies were established by Shafer (1958) at Paxton, Nebraska. Herbicides used were 2-(2,4-dichlorophenoxy) propionic acid [2-(2,4-DP]), polychlorobenzoic

${ }^{1}$ Published with the approval of the Director as Paper No. 1464, Journal Series, Nebraska Agricultural Experiment Station. This research work was partly financed by the Nebraska Department of Aeronautics, Lincoln, Nebraska.

2 Formerly Instructor in Agronomy, Dept. of Agronomy, Nebraska Agricultural Expt. Sta., Lincoln, Nebraska. acid (PBA), 2- (2-methyl-4-chlorophenoxy) propionic acid [2(MCPP) ], and silvex, applied by a ground sprayer. Silvex was most effective, giving 98 percent yucca control at $2 \mathrm{lb} / \mathrm{A}$.

This study was conducted to determine the most effective herbicide, herbicide carrier, and spray volume needed for aerial control of yucca in western $\mathrm{Ne}$ braska.

\section{Materials and Methods}

Aerial applications of herbicides were made on a Dune sand soil for yucca control at Angora, Nebraska. The dunes are sharply rolling and separated in many places by steep slopes, varying from 30 to 100 feet in height. A small proportion is under active wind erosion in blow-out areas. Annual average temperature is approximately $48^{\circ} \mathrm{F}$. Mean annual precipitation is 15.5 inches with the majority occurring in spring and summer.

Initial applications were made on June 5, 1958, with a Piper Super Cub. Each plot consisted of three flight strips, each 33 feet wide and 440 feet long (1 acre). Herbicide treatments consisted of the propylene glycol butylether (PGBE) ester of silvex at 1 and $2 \mathrm{lb} / \mathrm{A}$ in combination with nine herbicide carriers. One $1 \mathrm{~b} / \mathrm{A}$ of the PGBE ester of $2,4,5-\mathrm{T}$ in a $1: 1$ oil-water emulsion was included for comparison. Herbicide rates, carriers, and spray volumes per acre were applied as follows:

1. One $\mathrm{lb} / \mathrm{A} 2,4,5-\mathrm{T}$ in a $1: 1$ oil-water emulsion at 2 gpa

2. Two lb/A silvex in No. 2 diesel oil at 2 gpa

3. Two lb/A silvex in water at 2 gpa

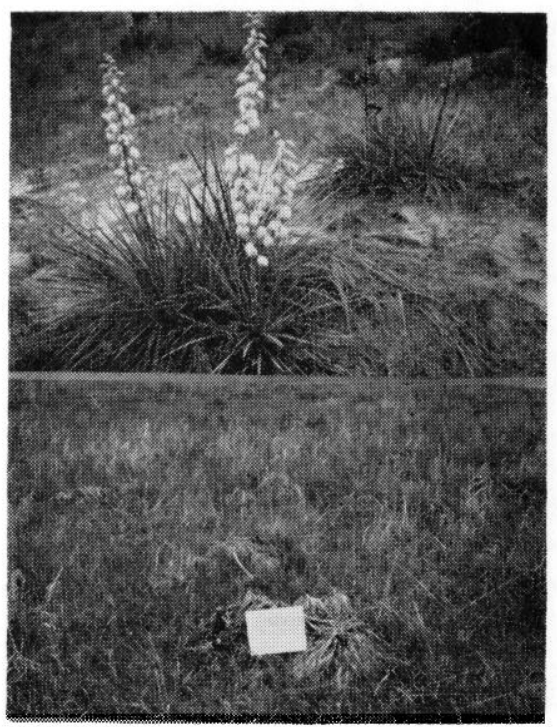

Figure 1. Top-Yucca in flower at Angora, Nebraska. June 18, 1963. BottomControl of yucca by application of single treatment of $2 \mathrm{lb} / \mathrm{A}$ silvex applied in No. 2 diesel oil at 5 gpa., June 17, 1960; photograph June 18, 1963. Note luxuriant native grass growth on treated area.

4. One $\mathrm{lb} / \mathrm{A}$ silvex in water at 2 gpa

5. Two $\mathrm{lb} / \mathrm{A}$ silvex in a $1: 1$ oil-water emulsion at 2 gpa

6. Two $\mathrm{lb} / \mathrm{A}$ silvex in a $1: 4$ oil-water emulsion at 5 gpa

7. One $1 \mathrm{~b} / \mathrm{A}$ silvex in water at 5 gpa

8. Two $\mathrm{lb} / \mathrm{A}$ silvex in water at 5 gpa

9. Two $\mathrm{lb} / \mathrm{A}$ silvex in No. 2 diesel oil at 5 gpa

10. Two $\mathrm{lb} / \mathrm{A}$ silvex in water at $10 \mathrm{gpa}$

Yucca control observations were made in October, 1958, and June, 1959. Final control evaluations were made in September, 1960 , on 10 yucca clumps selected at random in each plot by determining whether they were dead or alive. Percentage kill figures were then derived from these counts.

In 1960 , a second set of oneacre plots was sprayed at Angora with a Piper Super Cub as before. Treatments of PGBE ester of silvex at 1, 2, and $4 \mathrm{lb} / \mathrm{A}$. were applied in No. 2 diesel oil at 5 gpa total solution when yucca was flowering. Plots were 
treated initially on June 17, 1960. Repeat treatments on June 20, 1961, were the same herbicides and rates as original ones superimposed on one-half of the same plots. Percentage kill was determined by randomly selecting 15 yucca clumps in each plot and assigning a kill rating to each clump in a range of $0-10$. No control was given a value of 0 ; complete kill, 10 . The values obtained were converted to percentage kill.

A third experiment using different herbicide carriers and spray volumes was applied on June 20, 1961, to study their influence on yucca kill. Two lb/A of the PGBE ester of silvex was selected as the herbicidal treatment. Number 2 diesel oil, water, and water plus a surfactant (Multifilm X-77) were the three carriers used. Spray volumes were 2 and 5 gpa. Each plot was 2 flight strips (66 feet) wide and 240 feet long. Each treatment was replicated. Percentage kill was determined by randomly selecting 20 yucca plants or clumps in each plot which were evaluated in a similar manner for the June, 1960 , study. After control evaluations were made the plots were retreated on June 18, 1962, with treatments identical to those applied in June, 1961.

\section{Results and Discussion}

Observations made in October, 1958, four months after applications of silvex at Angora, Nebraska, revealed silvex at $2 \mathrm{lb} / \mathrm{A}$ applied in No. 2 diesel oil at 5 gpa gave most effective control. Silvex at $2 \mathrm{lb} / \mathrm{A}$ in No. 2 diesel oil at 2 gpa was considered the second most effective treatment. Silvex, at $2 \mathrm{lb} / \mathrm{A}$, applied in a $1: 1$ oil-water emulsion at 2 gpa and silvex at $1 \mathrm{lb} / \mathrm{A}$ in water at 5 gpa, were ranked third. In June, 1959, $2 \mathrm{lb} / \mathrm{A}$ silvex applied in No. 2 diesel oil at 5 gpa remained the most effective yucca control treatment, with an estimated 35 percent kill. The remaining yucca plants were very chlorotic and had not produced flower stalks. The next best treatment was silvex at $2 \mathrm{lb} / \mathrm{A}$ applied as a 1:1 oil-water emulsion at 2 gpa. The estimated kill was 30 percent with mostly chlorotic plants remaining. All other treatments produced less injury and kill. The plots receiving 1 $\mathrm{lb} / \mathrm{A}$ of 2,4,5-T showed no apparent control. Evaluations of the plots on September 16, 1960, are presented in Table 1 . Silvex at $2 \mathrm{lb} / \mathrm{A}$, applied in No. 2 diesel oil at a total spray solution of 5 gpa, remained the most effective treatment at 80 percent control. Silvex, at $2 \mathrm{lb} / \mathrm{A}$ applied as a 1:1 oil-water emulsion, was also a relatively effective treatment.

The 1960 studies aimed to determine what rate of silvex was most effective with the No. 2 diesel oil carrier at 5 gpa. Re-

Table 1. Percentage kill of yucca from single application of 2,4,5-T and silvex in combination with herbicide carriers and volumes per acre at Angora, Nebraska. Treatments June, 1958; evaluated, September, 1960.

\begin{tabular}{lcc}
\hline \multicolumn{1}{c}{ Herbicide and carrier } & Herbicide & Kill1 \\
\cline { 2 - 3 } $2,4,5-\mathrm{T}+1: 1$ emulsion at 2 gpa & (Lb/A) & (Pct) \\
Silvex + No. 2 diesel at 2 gpa & 1 & 0 \\
Silvex + water at 2 gpa & 2 & 30 \\
Silvex + water at 2 gpa & 1 & 30 \\
Silvex + 1:1 emulsion at 2 gpa & 2 & 70 \\
Silvex + 1:4 emulsion at 5 gpa & 2 & 50 \\
Silvex + water at 5 gpa & 1 & 30 \\
Silvex + water at 5 gpa & 2 & 80 \\
Silvex + No. 2 diesel oil at 5 gpa & 2 & 30 \\
Silvex + water at 10 gpa & 2 &
\end{tabular}

1Percentage kill was derived by evaluating at random ten plants. If any regrowth occurred following treatment, plants were considered alive.

Table 2. Percentage kill 1 of yucca after single and repeated applications of silvex in No. 2 diesel oil at spray volume of $5 \mathrm{gpa}$.

Time after application

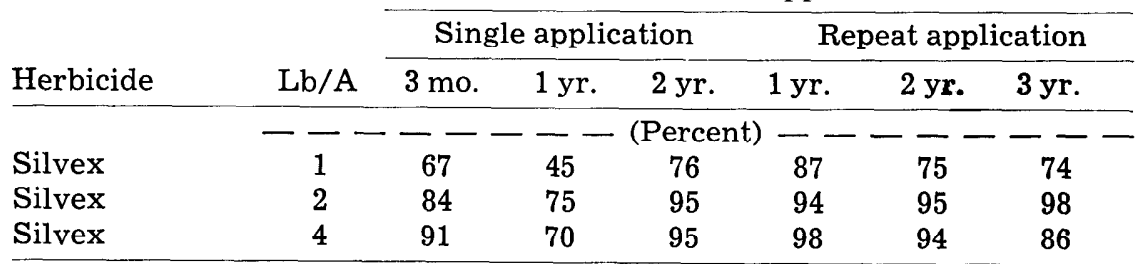

1Percentage kill was determined by evaluating 15 yucca plants in each plot. A kill evaluation based on total top kill was assigned each plant with no top kill given a value of 0 ; and complete top kill with no regrowth as 10 . Values for each plot were averaged and converted to percentage kill. 
control was obtained when 2 and $4 \mathrm{lb} / \mathrm{A}$ silvex were used as a single application. Plots treated with $4 \mathrm{lb} / \mathrm{A}$ silvex showed no increase in yucca kill over those treated with $2 \mathrm{lb} / \mathrm{A}$ silvex. The $1 \mathrm{lb} / \mathrm{A}$ rate of silvex gave 76 percent yucca control. There were no major changes in control values from 2 to 3 years after a single application of silvex from June, 1962, to June, 1963.

Additional herbicides were applied in June, 1961, to study the influence of carriers and spray volumes on yucca kill in more detail (Table 3). No significant differences were found between the 2 and 5 gpa spray volume treatments. No 2 diesel oil tended to be superior to other carriers at 2 and 5 gpa in combination with $2 \mathrm{lb} / \mathrm{A}$ silvex as a single application. Evaluations of repeated applications of silvex showed improved yucca control in all plots.

\section{Summary and Conclusions}

Preliminary studies of yucca control by aircraft applications revealed that silvex applied at 2 $\mathrm{lb} / \mathrm{A}$ in No. 2 diesel oil at 5 gpa total spray solution gave the best yucca kill from a single application of all herbicides, carriers, and spray volumes used. A substantial amount of yucca regrowth was found in all plots two years following treatment

Table 3. Percentage control ${ }^{1}$ of yucca one year after single and repeat applications of $2 \mathrm{lb} / \mathrm{A}$ silvex in No. 2 diesel oil, water, and water plus surfactant carriers at spray volumes of 2 and $5 \mathrm{gpa}$.

\begin{tabular}{|c|c|c|}
\hline Herbicide and Carrier & Single application & Repeated application \\
\hline & \multicolumn{2}{|c|}{$----($ Percent $)----$} \\
\hline Silvex + water at 2 gpa & 85 & 98 \\
\hline \multicolumn{3}{|l|}{ Silvex 1 water + surfactant ${ }^{2}$} \\
\hline at 2 gpa & 69 & 97 \\
\hline Silvex + No. 2 diesel oil at 2 gpa & 87 & 98 \\
\hline Silvex + water at $5 \mathrm{gpa}$ & 70 & 99 \\
\hline \multicolumn{3}{|l|}{ Silvex + water + surfactant ${ }^{2}$} \\
\hline at $5 \mathrm{gpa}$ & 86 & 98 \\
\hline Silvex + No. 2 diesel oil at 5 gpa & 93 & 99 \\
\hline
\end{tabular}

1Percentage kill was determined by evaluating 20 yucca plants in each plot. ${ }^{2}$ Alkylaryl polyoxyethelene glycol (Multifilm X-77 at $0.1 \%$ ).

indicating retreatment was necessary for best control.

In June, 1960, studies were conducted to determine the most economical and effective silvex rates to use in combination with No. 2 diesel oil. Results revealed that $2 \mathrm{lb} / \mathrm{A}$ of silvex gave as much yucca kill as $4 \mathrm{lb} / \mathrm{A}$. Repeat applications one year after initial treatment did not improve control. Some yucca regrowth occurred in all plots. Total regrowth was considered small and lacked regenerative vigor as indicated in counts taken 1, 2, and 3 years after treatment.

In a herbicide carrier-spray volume study established in June, 1961, no differences were found in yucca kill between 2 and 5 gpa spray volume treatments. No. 2 diesel oil applied as the silvex carrier tended to produce the best yucca kills from a single application. Repeated applications of identical treatments did increase kill.

For most economical and satisfactory results, yucca in western Nebraska should be treated with a single application of $2 \mathrm{lb} / \mathrm{A}$ silvex using No. 2 diesel oil as the carrier. Retreatment is expensive, consequently repeated applications should be made only if necessary. Sufficient regrowth to necessitate retreatment may not occur until several years after initial treatment.

\section{LITERATURE CITED}

Robison, E. D. 1961. Aerial application of herbicides for the control of yucca. Proc. 14th Ann. Southern Weed Conf.

Shafer, N. E. 1958. Use of aircraft in agriculture. Ann. Rpt. of Project 12-20. Nebraska Agr. Expt. Sta., Lincoln, Nebraska.

\section{NOTICE TO ALL MEMBERS}

New application cards and brochures citing new dues rate have been distributed to Sections. Please destroy all old brochures and application cards in your possession and, if you need them, order new from your Section Secretary. 